Uniwersytet w Białymstoku

Wydział Filologiczny

Instytut Filologii Wschodniosłowiańskiej

Katedra Językoznawstwa Historycznego

tel. +48 857457499

e-mail: m.kurianowicz@uwb.edu.pl

ORCID ID: https://orcid.org/0000-0001-7493-7523

\title{
Transformacje leksykalne cerkiewnosłowiańskich tekstów ewangelicznych redakcji ruskiej ${ }^{1}$
}

Słowa kluczowe: leksyka, starodruki, język cs. ruskiej redakcji, drugi wpływ południowosłowiański

Badania nad leksykologią Biblii słowiańskiej trwają od momentu powstania tekstologii Biblii jako nauki, czyli od połowy XVIII w. [Камчатнов 1998, 3]. Stanowią one przedmiot zainteresowań zarówno teologów, jak i slawistów, którzy swoją uwagę skupiali przede wszystkim na „oryginałach tłumaczeń" św. św. braci Cyryla i Metodego [Ostapczuk 2010, 188]. Stąd na przestrzeni dwóch stuleci tak wiele projektów dotyczących rekonstrukcji cs. tekstu Ewangelii [Kurianowicz 2015, 8-9].

Kwestię leksykalnych rozbieżności w zabytkach scs. i młodszego cs. piśmiennictwa podejmowali zarówno zagraniczni, jak i polscy językoznawcy. Wystarczy przytoczyć chociażby takie nazwiska jak: A. S. Lwow, A. I. Sobolewski, G. A. Woskresenski, V. Jagič, oraz bardziej współczesne L. P. Żukowskaja, R. M. Cejtlin, W. W. Kolesow, E. M. Vereszczagin, N. A. Meszczerski, W. M. Żiwow, A. A. Alekseew, L. Moszyński, T. Friedelówna,

\footnotetext{
1 Niniejszy artykuł stanowi skróconą i nieznacznie przeredagowaną wersję IV rozdziału rozprawy doktorskiej powstałej ze środków MNiSW na naukę, w ramach grantu promotorskiego nr N N104 0577438 pt. Biblia Ostrogska i XVIII-wieczna Ewangelia klasztoru w Jablecznej - cerkiewnostowiańskie zabytki redakcji ruskiej.
} 
A. Szulc, A. E. Żaguń. Jeśli chodzi o prace dotyczące wyłącznie leksyki biblijnej tekstów drukowanych, to wciąż należą one do rzadkości. W ostatnich latach ukazało się kilka artykułów, którego autorem jest pracownik naukowy Rosyjskiej Akademii Nauk F. B. Ludogowski. Wprawdzie w swoich badaniach skupia się on przede wszystkim na języku Akatystów, to kilka jego prac dotyczy analizy porównawczej młodszych (XVI-XX w.) cs. tekstów wykorzystywanych w cerkiewnej praktyce liturgicznej (tzw. cлyжебньл) z Ewangeliarzami przeznaczonymi do codziennego czytania przez wiernych w domu (tzw. четьих) [Людоговский 2005, 130-135; Людоговский 2006, 400-418]. Zatem podjęty w niniejszym artykule temat zdecydowanie wpisuje się w najnowszą linię badań nad historią cs. ewangelicznych tekstów drukowanych, które nie zostały dotąd zbadane [Людоговский 2006, 400-418].

Przedmiot niniejszej analizy porównawczej stanowi leksyka wyekscerpowana z trzech cs. tekstów redakcji ruskiej, które powstawały na przestrzeni ponad 700 lat: z Ewangeliarza Ostromira (dalej: EO) 1056-1057 r., Biblii Ostrogskiej (dalej: BO) - 1581 r., Ewangeliarza Jabteczyńskiego (dalej: EJ) - 1771 r. Do badań nad leksyką wykorzystany został rękopiśmienny Ewangeliarz Ostromira, jako zawierający kanoniczny tekst, gdyż jak stwierdza A. S. Lwow

лексические варианты должны анализироваться на основании данных контекста не только одного типа памятников, а всего круга памятников старославянской письменности, по крайней мере старших списков [Львов 1966, 18].

Z całego bogactwa form zostały wyekscerpowane tylko te jednostki, które stanowiły opozycję starodruków wobec kanonu i względem siebie. Celem takiego zestawienia było pokazanie różnic w doborze środków leksykalnych w tekście ewangelicznym ruskiej redakcji na przestrzeni ponad 700 lat oraz podjęcie próby naukowego wyjaśnienia samych przyczyn zarejestrowanych zmian.

Współczesna leksykologia słowiańska rejestruje cały wachlarz terminów na określenie zjawiska dyferencji leksykalnej napotkanej w scs. i cs. tekstach: warianty leksykalne, zamiany leksykalne, rozbieżności leksykalne, paralele leksykalne, dublety tekstologiczne, synonimy [Панин 1995, 79]. W niniejszej pracy przyjęta została terminologia ustalona w 1964 r. przez L. P. Żukowską [Жуковская 1976, 88-89], a kontynuowana i rozwinięta przez R. M. Cejtlin [Цейтлин 1977, 45-46, 52-53]. Przedmiotem poniższych rozważań będą dublety leksykalne, tj. pary (szeregi) wyrazów utworzone od różnych rdzeni, ale posiadające minimum jedno wspólne znaczenie [Цейтлин 1977, 52]. 
Aby przeprowadzić analizę leksykalną cs. tekstów nie wystarczy dokonać ich klasyfikacji. Należy przede wszystkim podjąć próbę ukazania źródła leksykalnych rozbieżności (ustalić kryteria doboru leksyki) oraz określić charakter napotkanych zmian. Do chwili obecnej, pomimo podejmowanych licznych prób, nie udało się określić jednoznacznych przyczyn występowania w tekstach różnic leksykalnych [Львов 1974, 78-90]. Często wiąże się to z tym, że większość tekstów, na podstawie których prowadzane są badania języka scs. i cs., została przetłumaczona z języka greckiego. Jednak, pomimo iż greckimi oryginałami słowiańskich przekładów nauka nie dysponuje [Логачев 1988, 7; Верещагин 1971, 18], to językoznawcy w swoich badaniach wykorzystują bardziej lub mniej udaną rekonstrukcje pierwowzoru (często określoną jego redakcją) $)^{2}$, nie zawsze jednak trafną. A oparcie się na innej wersji greckiego oryginału może doprowadzić do błędnych wniosków. Źródłem, stanowiącym grecką podstawę niniejszych rozważań jest przekład ks. R. Popowskiego oraz M. Wojciechowskiego Grecko-polski Nowy Testament wydanie interlinearne z kodami gramatycznymi, dokonany na podstawie tekstu The Greek New Testament, ed. K. Aland, M. Black, C. M. Martini, B. M. Metzger, A. Wikgren (Stuttgart).

Ze względu na charakter zarejestrowanych w tekstach rozbieżności leksykalnych wyekscerpowany materiał został podzielony na trzy grupy. Pierwsza z nich, najliczniejsza, przeciwstawia leksykę EO leksyce BO i EJ $(\mathrm{BO}=\mathrm{EJ})$. Druga grupa zawiera oboczności, w których leksyka EO i BO jest zbieżna $(\mathrm{EO}=\mathrm{BO})$, ale niezgodna z leksyką EJ. Z kolei ostatnią grupę stanowią dublety, w których tożsama leksyka EO i EJ (EO=EJ) stanowi opozycję w stosunku do leksyki BO.

\section{Leksyka EO przeciwstawia się leksyce BO i EJ $(\mathrm{BO}=\mathrm{EJ})$}

\section{1. leksem słowiański $(\mathrm{EO}) \Rightarrow$ leksem słowiański $(\mathrm{BO}=\mathrm{EJ})$}

Pierwsze teksty liturgiczne autorstwa św. św. Braci powstały jako pomoc w prowadzeniu misji chrystianizacji na terenie Wielkich Moraw i Panonii ${ }^{3}$. W celu przybliżenia ich do języka Morawian, tłumaczenia słowiań-

2 Problem greckiego materiału porównawczego dla cs. przekładu Ewangelii nadal pozostaje otwarty. Próby oceny greckich źródeł podjął się m.im. prof. A. A. Alekseew [Алексеев 1999, 200-210] oraz w swojej pracy doktorskiej J. Ostapczuk [Ostapczuk 2010, 149-187]. Według K. I. Logaczewa najodpowiedniejszym byłby tekst Ewangelii z IX w. typu bizantyjskiego [Логачев 1976, 94-99].

3 Szerzej o zasadach, jakimi kierowali się św. św. Cyryl i Metody w swojej pracy translatorskiej zob. m.in.: Верещагин 1971, 23-126; Moszyński 1969, 552-564; Szulc 2000, $26-31$. 
skie poddane zostały redakcji, w wyniku której wyrazy południowosłowiańskie (bułgarskie) zostały zastąpione przez lokalne - morawskie [Rusek 1984, 190-191]. Przez stulecia te zachodniosłowiańskie elementy leksykalne przedostawały się do odpisów i przez co rozpowszechniły się w późniejszych tekstach. Stąd cs. redakcje, choć mniej lub bardziej odległe od czasów i terenów misji św. św. Braci, zawierają pewną ilość morawizmów odziedziczonych z pierwowzorów, na podstawie których powstały [Friedelówna 1974, 198]. Bez wątpienia, tekst EO w porównaniu z BO i EJ zawiera o wiele więcej takich poświadczeń, co można tłumaczyć jego względną bliskością z czasami św. św. Cyryla i Metodego ${ }^{4}$, por.:

\begin{tabular}{|c|c|c|c|}
\hline $\mathrm{EO}$ & $\mathrm{BO}$ & EJ & \\
\hline отЪ нєпригазни & $\Rightarrow$ W $\Lambda$ ४каBaro & $\Rightarrow \mathbf{\omega}$ А 8 кавагw & 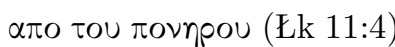 \\
\hline пастоуси & $\Rightarrow$ пастырїє & $\Rightarrow$ пастырїє & 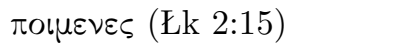 \\
\hline МьЗАОнМьць & $\Rightarrow$ мытарь & $\Rightarrow$ мытарь & $\tau \varepsilon \lambda \omega \nu \eta \varsigma$ ( $\mathrm{kk} 18: 13$ ) \\
\hline година & $\Rightarrow$ часъ & $\Rightarrow$ часъ & $\omega \rho \alpha(\mathrm{J} 2: 4)$ \\
\hline юдини & $\Rightarrow$ мкцїн & $\Rightarrow$ м'ццыи & 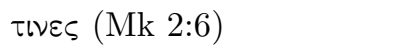 \\
\hline Кднномог & $\Rightarrow$ н'коемУ & $\Rightarrow$ н'коємУ & $\tau \iota v \alpha(\mathrm{Mk} 15: 21)$ \\
\hline Apoyraaro & $\Rightarrow$ єАїного & $\Rightarrow$ єдннаго & $\varepsilon \vee \alpha(\mathrm{Mk} 15: 27)$ \\
\hline
\end{tabular}

Konfrontacja cs. tekstów wykazała również obecność dubletów zawierających archaiczną warstwę słownictwa (morawizmy) w tekstach młodszych $(\mathrm{BO}=\mathrm{EJ})$, którym w EO przeciwstawione zostały obocznie występujące odpowiedniki południowosłowiańskie, por.:

\begin{tabular}{|c|c|c|c|}
\hline $\mathrm{EO}$ & $\mathrm{BO}$ & EJ & \\
\hline распьнхть & $\Rightarrow$ пропн४тть & $\Rightarrow$ пропн४тиь & $\sigma \tau \alpha \cup \rho \omega \sigma \omega \sigma \iota \nu(\mathrm{Mk} 15: 20)$ \\
\hline жизнь & $\Rightarrow$ жнвотъ & $\Rightarrow$ животъ & $\zeta \omega \eta \nu($ Mt 25:46) \\
\hline
\end{tabular}

Kolejna redakcja liturgicznych ksiąg cerkiewnych miała miejsce już w Bułgarii, dokąd po upadku misji w 885 r. udali się uczniowie św. św. Cyryla i Metodego. Powstałe tu u schyłku IX w. dwa wielkie centra cs. piśmiennictwa: presławskie - założone we wschodniej części państwa bułgarskiego, oraz ochrydzkie - usytuowane w jego zachodniej części, pomimo iż bazowały na tym samym cs. języku, jednak na różnych jego dialektach ${ }^{5}$, to posiadały odmienny stosunek do cyrylometodejskiej spuścizny. Szkoła w Presła-

4 Proweniencja leksemów została ustalona na podstawie prac A. S. Lwowa, L. Moszyńskiego, A. Szulc, J. Ruska w konfrontacji ze słownikami (zob. Literatura).

5 Centrum presławskie opierało się na dialektach wschodnich (bułgarskich), a ochrydzkie - na zachodnich (macedońskich). 
wiu świadomie wprowadzała do przekładów osobliwości leksykalne swego środowiska, zachowując przy tym wierność pod względem formy oraz sensu greckiemu oryginałowi, podczas gdy centrum piśmiennicze w Ochrydzie przejawiało skłonność do tradycjonalizmu poprzez zachowanie dziedzictwa św. św. Cyryla i Metodego w jego niezmienionej formie ${ }^{6}$. Obie szkoły oddziaływały na siebie, czego dowodem są licznie poświadczone w kolacjonowanych tekstach leksykalne oboczności, polegające na zamianie słownictwa presławskiego (EO) leksyką ochrydzką $(\mathrm{BO}=\mathrm{EJ})$, por.:

\begin{tabular}{|c|c|c|c|}
\hline EO & $\mathrm{BO}$ & EJ & \\
\hline МЬЗАОНМЬЦЬ & $\Rightarrow$ мытарь & $\Rightarrow$ мытарь & $\tau \varepsilon \lambda \omega \nu \eta \varsigma$ (Ek 18:13) \\
\hline пастогси & $\Rightarrow$ пастырїє & $\Rightarrow$ пастырїє & 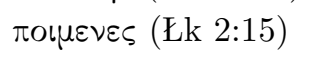 \\
\hline БаГърАннцд & 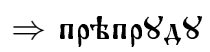 & $\Rightarrow$ ПрєпранA & ropqupar (Mk 15:20) \\
\hline СЪворнце & $\Rightarrow$ сонмнце & $\Rightarrow$ сонмнце & 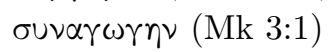 \\
\hline ЦАT及 & $\Rightarrow$ зАатицУ & $\Rightarrow$ зАатицУ & $\nu о \mu เ \sigma \mu \alpha($ Mt 22:19) \\
\hline
\end{tabular}

jak też ochrydzkiego (EO) leksyką presławską $(\mathrm{BO}=\mathrm{EJ})$, por.:

\begin{tabular}{|c|c|c|c|}
\hline $\mathrm{EO}$ & $\mathrm{BO}$ & EJ & \\
\hline Година & $\Rightarrow$ часъ & $\Rightarrow$ часъ & $\omega \rho \alpha(\mathrm{J} 2: 4)$ \\
\hline E'TEPß & $\Rightarrow$ нъкїи & $\Rightarrow$ нłкїй & tis (Łk 1:5) \\
\hline 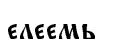 & $\Rightarrow$ масмомъ & $\Rightarrow$ Масломъ & $\varepsilon \lambda \alpha \iota \omega(\mathrm{Mk} 6: 13)$ \\
\hline когръ & $\Rightarrow$ n'tTEAb & $\Rightarrow \mathbf{\Pi \epsilon T \epsilon \Lambda \mathbf { b }}$ & $\alpha \lambda \varepsilon x \tau \circ \rho \alpha($ Mk 14:72) \\
\hline
\end{tabular}

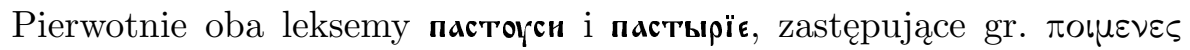
'pasterze', były wariantami i mogły występować w tekstach zamiennie: naстоYX’ъ jako 'pastuch, stróż stada', 'przywódca, przewodnik', 'pasterz'; naстырь w znaczeniu 'pastuch, stróż stada', 'przewodnik, przywódca'. Z upływem czasu ich semantyka uległa dyferencjacji i leksem пастоr’’ utrwalił się w dosłownym znaczeniu 'pastuch, przewodnik stada', natomiast element leksykalny пастырь w sensie przenośnym - 'pasterz, kapłan' [Панин 1995, 173]. Dlatego też pojawienie się w starodrukach wyrazu пастырь można tłumaczyć nie tylko wpływem szkoły ochrydzkiej, ale i przemianami semantycznymi, jakim na przestrzeni czasu uległy oba rzeczowniki.

Z kolei leksem o wschodniobułgarskiej proweniencji цхта 'cata, drobna moneta' gr. $\nu o \mu \iota \sigma \mu \alpha$ 'moneta' w starodrukach został oddany za pomocą synonimu o tej samej proweniencji зматица 'moneta'. Dubletem leksemu цхта jest również zarejestrowany $\mathrm{w}$ tekstach drukowanych wyraz nłassь, odpo-

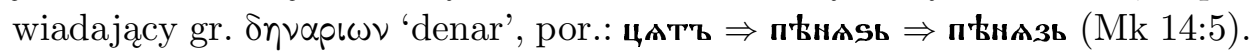

6 O zasadach, jakimi kierowały się obie szkoły przy doborze leksyki zob. Dąbek-Wirgowa 1980, 15-31; Szulc 2000, 33-36; Rusek 1984, 191-193. 
Przytoczony materiał zaświadcza o tym, iż tłumacze EO oddając dwa różne greckie leksemy użyli jednego wyrazu цАта. Z kolei przeprowadzona w starodrukach analiza dotycząca użycia leksemów зматнца і пłнаsь wykazała ich rozróżnienie w zależności od kontekstu. Leksem зматица został użyty wszędzie tam, gdzie występował w połączeniu z grecyzmem кинсонъ "poda-

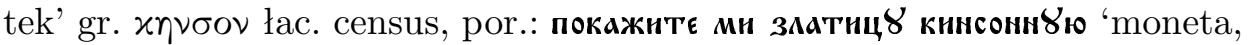
którą się płaci podatek' (Mt 22:19). Z kolei ogólny leksem nłнAss służył jako odpowiednik wszystkich pozostałych, obcych jednostek pieniężnych (gr. $\alpha \sigma-$

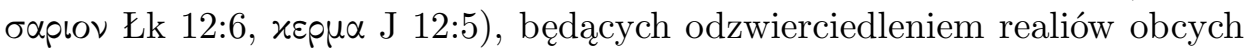
Słowianom. Pozostawienie w tekście specjalnego terminu 'denar' utrudniałoby zrozumienie tekstu i mogłoby odciągać czytelnika od treści ważniejszych.

Wśród przytoczonych powyżej dubletów leksykalnych na uwagę zasłu-

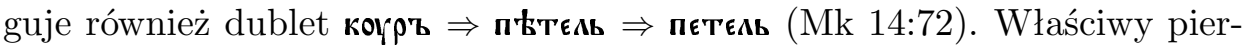
wotnemu przekładowi ogólnosłowiański wyraz коrръ zastąpiony został w językach wschodniobułgarskich (X w.) oraz południowosłowiańskich przez п'tтєsь. U południowych Słowian przyczyną zamiany było ustalenie się w leksemie когръ nowego, pejoratywnego znaczenia [Rusek 1984, 121-125]. Dlatego też wraz z tzw. drugim wpływem południowosłowiańskim na Ruś

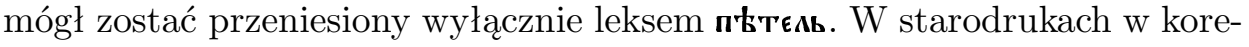

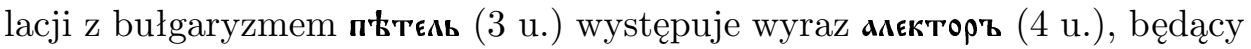
przejawem grecyzacji tekstów słowiańskich ${ }^{7}$.

Analiza porównawcza trzech tekstów pozwoliła na wyodrębnienie jeszcze jednej grupy dubletów, w której element presławski bądź ochrydzki zostaje zastąpiony przez wyraz pochodzenia wschodniosłowiańskiego, por.:

\begin{tabular}{|c|c|c|c|}
\hline $\mathrm{EO}$ & $\mathrm{BO}$ & EJ & \\
\hline EE30YMa & $\Rightarrow \mathrm{T} \mathbf{Y}_{\mathrm{HE}}$ & $\Rightarrow \mathrm{T} \boldsymbol{\gamma}_{\mathrm{HE}}$ & $\delta \omega \rho \varepsilon \alpha \nu$ (J 15:25) \\
\hline $\operatorname{axpcA}$ & $\Rightarrow$ в БВАЕ БВХУ & 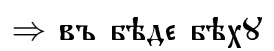 & 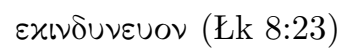 \\
\hline кони 8 & $\Rightarrow$ внаYаA' & $\Rightarrow$ BЪ началt & $\varepsilon \nu \alpha \rho \times \eta(\mathrm{J} 1: 1)$ \\
\hline прьва & $\Rightarrow$ ИЗНАЧААА & $\Rightarrow$ иЗНачала & $\alpha \pi$ apхns (Mt 19:8) \\
\hline
\end{tabular}

W XIV w. kolejna reforma słownictwa, która ze względu na czas jej przeprowadzenia mogła zostać odzwierciedlona tylko w tekście BO i EJ, związana była z osobą patriarchy Eutymiusza, twórcą tzw. szkoły tyrnowskiej. Pisarze tyrnowscy czerpali zarówno ze szkoły presławskiej, jak i ochrydzkiej, jednak o dystrybucji wyrazu decydowała nie jego proweniencja, a frekwencja użycia oraz zrozumiałość tłumaczenia i dokładność, ale niekoniecznie dosłowność [Rusek 1984, 193]. Stąd w tekstach drukowanych presławskie н'kкïn

\footnotetext{
7 Zob. niżej, par. 1.4 .

8 Zob. poniżej przekład morfemowy.
} 
$\Rightarrow$ н'ккїй (Łk 1:5), масломъ (Mk 6:13) oraz ochrydzkie пастырїє (Łk 2:15), сонмнце (Mk 3:1).

Na Rusi, gdzie od połowy XIV w. utrzymywano żywe kontakty z Konstantynopolem i Athosem (...) w przeróbce ksiąg kościelnych wiernie trzymano się wzorów tyrnowskich i nastał okres tzw. drugiego wpływu południowosłowiańskiego [Dąbek-Wirgowa 1980, 47].

Spuścizną po szkole tyrnowskiej jest zapewne szeroko zarejestrowany w starodrukach syntetyczny sposób przekładu. Wyeliminował on powszechnie używane w EO tłumaczenie analityczne (charakterystyczne dla szkoły ochrydzkiej), por.:

\begin{tabular}{|c|c|c|c|}
\hline EO & $\mathrm{BO}$ & EJ & \\
\hline вђрд жшж & $\Rightarrow$ в'вроваша & $\Rightarrow$ в'вроваша & $\varepsilon \pi \iota \sigma \tau \varepsilon \cup \sigma \alpha \nu(\mathrm{J} 2: 22)$ \\
\hline нє имњахх вњры & $\Rightarrow$ нє вЊровах४ & $\Rightarrow$ нє вњровахУ & 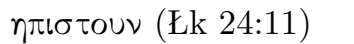 \\
\hline ИЧЬТЕНЪ БЫСТЬ & $\Rightarrow$ вмьнисл & $\Rightarrow$ вмьниса & 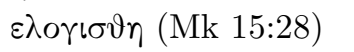 \\
\hline БЖАЕТЬ Познано & $\Rightarrow$ HE ПОЗНАЕТС A & $\Rightarrow$ HE ПОЗНАєТСА & $\gamma \nu \omega \sigma \vartheta \eta \sigma \varepsilon \tau \alpha \iota$ (Łk 8:17) \\
\hline сйсєни БХДХТт & 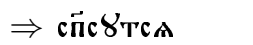 & $\Rightarrow$ спасУтесА & $\sigma \omega \vartheta \omega \sigma L($ Łk 8:12) \\
\hline
\end{tabular}

Język BO i EJ rejestruje dużą ilość jednostek leksykalnych, próbujących w sposób dokładny oddać grecki sens (przekład wyrazowy) [Верещагин 1971, 35-39]. Dbałość o maksymalne zbliżenie języka przekładu do greckiego oryginału był typową zasadą, którą stosowali tłumacze wywodzący się pierwotnie ze szkoły presławskiej, a następnie uczniowie Eutymiusza Tyrnowskiego. To właśnie poprzez ich działalność powyższa tendencja w XIV w. dotarła na Ruś (tzw. drugi wpływ południowosłowiański) i uzyskała szerokie zastosowanie, por.:

\begin{tabular}{|c|c|c|c|}
\hline $\mathrm{EO}$ & $\mathrm{BO}$ & EJ & \\
\hline ТஈKAЪMB & $\Rightarrow$ възрастомъ & $\Rightarrow$ возрастомъ & $\eta \lambda \iota x \iota \alpha(\operatorname{Ek~19:3)}$ \\
\hline ГӒАаше чнсто & $\Rightarrow$ ГйАаше право & $\Rightarrow$ Гйдашє правш & 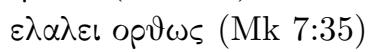 \\
\hline ъотрочины & $\Rightarrow$ изА 'ктека & $\Rightarrow$ изА 'ктска & $\pi \alpha \iota \delta เ ৩ \vartheta \varepsilon \nu(M k$ 9:21) \\
\hline жасостаса & $\Rightarrow$ АнвистасА & $\Rightarrow$ АнвистасА & $\varepsilon \xi \varepsilon \sigma \tau \eta \sigma \alpha \nu$ (Łk 8:56) \\
\hline
\end{tabular}

Doskonałym odzwierciedleniem dążenia do zgodności z teksem greckim z jednej strony, a chęcią uchronienia języka słowiańskiego od zbędnych obcych elementów - z drugiej, jest zastosowany w BO i EJ przekład morfemowy, polegający na zachowaniu kolejności kalkowanych członów. Dzięki takiej metodzie tłumaczenia uzyskano maksymalną zgodność z greckim oryginałem, nie tylko pod względem znaczeniowym, ale i formalnym, zachowując przy tym „narodowy charakter przekładu słowiańskiego” [Moszyński 1969, 552-564], por.: 


\begin{tabular}{|c|c|c|c|}
\hline EO & $\mathrm{BO}$ & EJ & \\
\hline ЮднночААЫй & $\Rightarrow$ ЮАїнОрОАный & $\Rightarrow$ ЕАннорОдный & 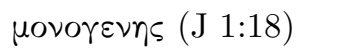 \\
\hline Арагы & $\Rightarrow$ многоцҺнны & $\Rightarrow$ многоц Бнны & $\pi \circ \lambda \cup \tau \varepsilon \lambda$ ous (Mk 14:3) \\
\hline искони & $\Rightarrow$ вначах & $\Rightarrow$ въ началь & $\varepsilon \nu \alpha \rho \times \eta(\mathrm{J} 1: 1)$ \\
\hline прьва & $\Rightarrow$ нзначама & $\Rightarrow$ изНачаАа & $\alpha \pi$ apхns (Mt 19:8) \\
\hline ББротворите & $\Rightarrow$ БӒГО ТВорНТЕ & $\Rightarrow$ БйГОТтвориТЕ & 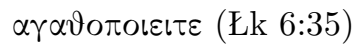 \\
\hline
\end{tabular}

Wybór jednego z dwóch lub więcej synonimów tworzących dublety na miejscu tego samego greckiego odpowiednika często mógł być uwarunkowany przemianami semantycznymi, jakiemu ulegało scs. słownictwo. Z jednej strony zakres semantyczny wyrazu zawężał się, z drugiej - ulegał rozszerzeniu. To z kolei spowodowało powstanie oboczności składających się z elementów pierwotnie różnych, często nawet o nie zbliżonych do siebie znaczeniach [Friedelówna 1974, 179], por.:

\begin{tabular}{|c|c|c|c|}
\hline $\mathrm{EO}$ & $\mathrm{BO}$ & EJ & \\
\hline СКрЪБАЧА & $\Rightarrow$ БОлАца & $\Rightarrow$ БОААЧ & 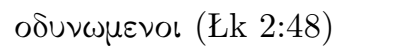 \\
\hline равъ & $\Rightarrow$ отрокъ & $\Rightarrow$ отршкъ & $\pi \alpha \iota \omega \omega \nu$ (Łk 15:26) \\
\hline оуБижть & $\Rightarrow$ OУМРБТВАТЬ & $\Rightarrow$ OУМЕРТВАТЬ & $\vartheta \alpha \nu \alpha \tau \omega \sigma \alpha l(\mathrm{Mk} 14: 55)$ \\
\hline Храмъ Бӝни & $\Rightarrow$ домъ кёїи & $\Rightarrow$ АОмъ вӝїй & 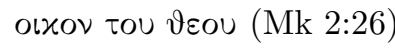 \\
\hline въ Танмицихъ & $\Rightarrow$ въ Храм'ххъ & $\Rightarrow$ во храм'ххъ & 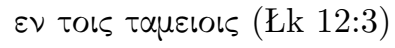 \\
\hline ГОАнна & $\Rightarrow$ часъ & $\Rightarrow$ часъ & $\omega \rho \alpha(\mathrm{J} 2: 4)$ \\
\hline АOЖE & $\Rightarrow$ OAPъ & $\Rightarrow$ ОАръ & $x \lambda เ \nu เ \delta เ$ เ ( $($ k 5:24) \\
\hline вьртьпъ & $\Rightarrow$ врьтоградъ & $\Rightarrow$ вертТГГААД & 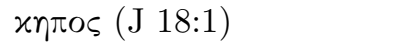 \\
\hline
\end{tabular}

Przykładem zawężenia znaczenia jest dublet скръБмща $\Rightarrow$ БолАща $\Rightarrow$ Бо-

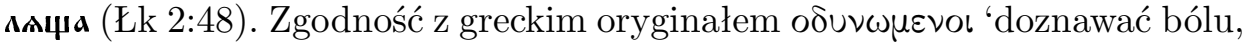
cierpieć', używanym zarówno w odniesieniu do udręki cielesnej, jak i duchowej (psychicznej), wykazuje leksem zarejestrowany w EO - скорь'вти 'chorować', ale i 'smucić się'. Powodem zastąpienia wyrazu скръвмща wyrazem волАща było właśnie zawężenie znaczenia przez leksem скорьњти na rzecz 'smucić się'. W XVI w., gdy dokonywano przekładu BO, wyraz скорь'тти odbierany był już wyłącznie w sensie psychicznym, duchowym. Stąd obocznоść скръБАща $\Rightarrow$ БОлАща $\Rightarrow$ БОлАща (Łk 2:48).

Z kolei w celu oddania gr. oıxos 'dom, mieszkanie' użyte zostały dwa słowiańskie leksemy храмъ (BO) oraz домъ (BO, EJ) (Mk 2:26). Pierwotnie posiadały one różne znaczenia ${ }^{9}$, jednak pierwsi kopiści nie odczuwali

9 Leksem домъ оznaczał 'mieszkanie wraz z mieszkańcami, ród', a храмъ 'budynek, gmach, pomieszczenie'. Dodatkowo wyraz храмъ w zabytkach scs., w odróżnieniu od neutralnego домъ, był nacechowany stylistycznie posiadał znaczenie 'dom Boży, świątynia'. 
semantycznej różnicy między nimi i dlatego często używali ich wymiennie [Львов 1966, 257-258]. Leksem домъ charakteryzował przekłady aprakosów, natomiast $\mathrm{w}$ tetrach jego odpowiednikiem był wyraz храмъ. Według J. Ruska zamiana домъ na храмъ nastąpiła bardzo wcześnie, bo jeszcze podczas redagowania tekstu Ewangelii na Morawach [Rusek 1984, 57]. Efekt tej korekty odzwierciedlony został $\mathrm{w}$ analizowanych tekstach: XI-wieczny aprakos zachowuje wyraz храмъ, a teksty drukowane - домъ. Przyczyną zamiany było najprawdopodobniej uszczuplenie wartości semantycznej wyrazu храмъ. W X-XI w. leksem z rdzeniem * chorm- w swoim podstawowym znaczeniu 'budynek, gmach, pomieszczenie' wyszedł z użycia [Львов 1966, 258], zachowując jedynie poszerzenie semantyczne 'dom Boży, świątynia', które ostatecznie utrwaliło się jako jego znaczenie podstawowe [Rusek 1984, 60]. Z ko-

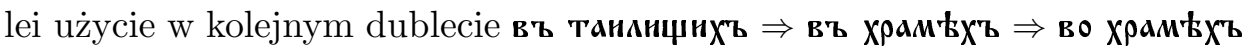

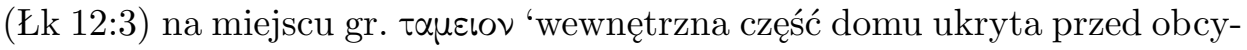
mi' leksemu храмъ w jego pierwotnym znaczeniu 'budynek, gmach, pomieszczenie' mogło być spowodowane kilkoma czynnikami. Po pierwsze przejęciem go bezpośrednio z prototypu, na podstawie którego powstawały teksty drukowane. Po drugie, próbą dokładnego oddania sensu greckiego oryginału - zasadą translatorską charakterystyczną dla tyrnowskiej szkoły przekładu, przeniesioną na Ruś w XIV w. w wyniku tzw. drugiego wpływu południowosłowiańskiego. Leksem храмъ mógł być również wprowadzony jako archaizm, typowy dla pierwszych przekładów aprakosów.

Przykładem pary dubletów leksykalnych różniących się początkowo swoim znaczeniem jest również oboczność ^ожє 'miejsce do leżenia, pościel' oraz -дръ 'nosze służące do przenoszenia rzeczy lub osób, grób'. Pierwsze scs. teksty używają powyższych leksemów wymiennie, jako synonimy. Stąd wniosek, iż redaktorzy nie rozróżniali ich znaczeń ${ }^{10}$, a użycie danego wyrazu uzależnione było od rodzaju tekstu: w Ewangeliarzach pojawiał się przede wszystkim leksem одръz, w pozostałych tekstach - ложє [Львов 1966, 169]. Jednak rzeczownik можє bardzo wcześnie wyszedł z użycia we wschodniobułgarskich dialektach, a jego miejsce zajął leksem oApъ ${ }^{11}$. W związku z tym, iż EO w odniesieniu do BO i EJ powstał stosunkowo wcześnie, a przez to w większym stopniu zbliżony jest do pierwszego cyrylometodejskiego przekładu, jego język rejestruje leksem $\mathbf{ю ж є , ~ k t o ́ r e g o ~ o d p o w i e d n i k i e m ~ w ~ e w a n g e l i c z - ~}$ nych tekstach drukowanych jest oдpr.

\footnotetext{
10 Zob. również Львов 1966, 171.
}

11 Dialekty zachodniobułgarskie do dnia dzisiejszego nie znają słowa oApъ w znaczeniu 'łóżko, pościel' [Львов 1966, 172]. Stąd wniosek, iż powyższe dwa leksemy nie mogły występować zamiennie ani na Morawach, ani w Panonii. 
Leksem вєртоградъ 'ogród, sad', gr. хүлоৎ 'ogród', charakterystyczny dla zasobu leksykalnego południowej Słowiańszczyzny, w szczególności dla języka macedońskiego [Львов 1974, 78-90], jest kolejnym przykładem zwrócenia się redaktorów tekstów drukowanych do archaicznej leksyki, zarejestrowanej w pierwszych scs. przekładach. Wyraz вєртоградъ zastąpił w EO wschodniosłowiański вьртьпъ, którego pierwotne znaczenie oscylowało wokół 'grota, pieczara, sad'. Z upływem lat jego zakres semantyczny uległ zawężeniu i utrwalił się ostatecznie jako 'grota, pieczara'. Dlatego też w XVI w. korektorzy mogli uznać go za element nieadekwatny do kontekstu i niezgodny z greckim oryginałem, co spowodowało zwrócenie się do archaicznej warstwy scs. leksyki i wprowadzenie na miejscu gr. xnлos południowosłowiańskiego odpowiednika вєртоградъ.

Zmiany semantyczne powiązane były często ze zmianami stylistycznymi. W tekstach drukowanych zauważyć można tendencję do zastępowania elementów leksykalnych neutralnych stylistycznie (EO) poprzez jednostki nacechowane, o większej sile ekspresji, por.:

\begin{tabular}{|c|c|c|c|}
\hline $\mathrm{EO}$ & $\mathrm{BO}$ & EJ & \\
\hline доврt & $\Rightarrow$ ENA3t & $\Rightarrow$ EAd3t & $\alpha \gamma \alpha \vartheta \eta \nu$ (Łk 8:8) \\
\hline доБрыи & $\Rightarrow \overrightarrow{\text { Б八ГГый }}$ & $\Rightarrow \overrightarrow{\text { БАГІІй }}$ & 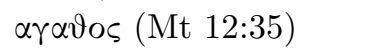 \\
\hline АЬНЬ ВЕАНКЫИ & $\Rightarrow$ праздмнкъ & $\Rightarrow$ праздникъ & 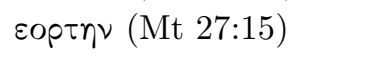 \\
\hline змый & $\Rightarrow$ А४кавыи & $\Rightarrow$ А४кавый & 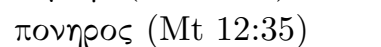 \\
\hline$\vec{\Gamma} \mathbf{b}$ домоу & $\Rightarrow$ АОМУ вАิка & $\Rightarrow$ АОМУ ВА̃Ка & 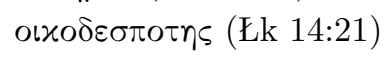 \\
\hline СЪТВОрЕнЪ & $\Rightarrow$ съЗААнъ & $\Rightarrow$ с0зданъ & 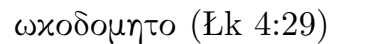 \\
\hline
\end{tabular}

Przykładowo, leksem доврын ${ }^{12}$ używany był przez tłumaczy w celu określenia 'tego co dobre, uznane, aprobowane', а вйгый - częściej stosowano w odniesieniu do człowieka, w celu podkreślenia jego dobrej moralności [Szulc 2000, 68]. We fragmencie Mt 12:35 przymiotnik łączy się właśnie

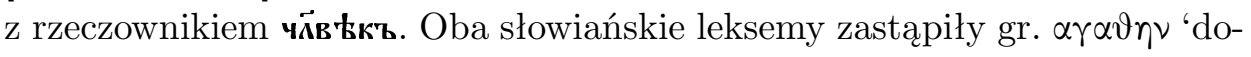
bry' posiadający zarówno odcień neutralności, jak i nacechowania, w zależności od kontekstu: 'dobry w znaczeniu ogólnym' oraz 'dobry moralnie' człowiek. Stąd wynika, że to słowiańscy redaktorzy starodruków, wychodząc dalej niż wymagał tego od nich grecki oryginał, w celu podkreślenia stylistycznego nacechowania, wprowadzili dwa bliskoznaczne wyrazy. Takiego rozróżnienia nie spotykamy w EO. Podobny odcień posiada antonimiczny dublet змый $\Rightarrow$ А४кавыи $\Rightarrow$ А४кавый (Mt 12:35).

12 Zob. Kondratiuk 2003, 515. 
Zarejestrowana została również sytuacja odwrotna, w której redaktorzy starodruków zamiast wariantu nacechowanego stylistycznie (EO) wybrali jego neutralny odpowiednik $(\mathrm{BO}=\mathrm{EJ})$, por.:

EO

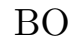

оржасостасл

$$
\Rightarrow \text { АнвистасА } \quad \Rightarrow \text { АнвистасА }
$$$$
\varepsilon \xi \varepsilon \sigma \tau \eta \sigma \alpha \nu(\text { Łk 8:56) }
$$

Użycie w BO i EJ neutralnego, bez dodatkowego emocjonalnego zabarwienia leksemu дивистасл 'dziwić się' na miejscu оүжасостас⿱ 'przerazić się', 'niepokoić się, być wzburzonym', 'zdziwić się, zdumieć się', 'wpaść w zdumienie', z jednej strony wywołane jest greckim źródłem ( $\varepsilon \xi \varepsilon \sigma \tau \eta \sigma \alpha \nu$ 'dziwili się'), a z drugiej - kontekstem: rodzice zmarłej dziewczynki zdumieli się, gdy zobaczyli, jak Jezus przywrócił ją do życia (Łk 8:56). Użyta w EO jednostka leksykalna oүжасостас⿱ posiada wyraźnie zaakcentowany odcień ekspresywny [Kondratiuk 2003, 517], wyrażający 'silne uczucie strachu', 'skrajne zdziwienie'.

Liczną grupę dubletów powstałych w wyniku zmian stylistycznych, stanowią również czasowniki oznaczające ruch. Pary te, znamienne już dla najstarszych scs. zabytków [Михайловская 1978, 139-172], zostały zarejestrowane również $\mathrm{w}$ poddanych analizie cs. tekstach, por.:
$\mathrm{EO}$
$\mathrm{BO}$
EJ
HAєT'

$$
\Rightarrow \text { грАAETr }
$$$$
\Rightarrow \text { ГPAAET' }
$$

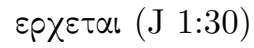
на$$
\Rightarrow \text { грАA } 8
$$$$
\Rightarrow \text { граА }
$$$$
\pi \varepsilon p l \pi \alpha \tau \text { touvtl (J 1:36) }
$$
Мнмонды
$\Rightarrow$ мнмограды
$\Rightarrow$ мнмогрАдый
$\pi \alpha p \alpha \gamma \omega \nu(\mathrm{Mk} 2: 14)$

Powstawanie oboczności semantycznych często wiązało się z eliminacją wyrazów wieloznacznych (EO) i wprowadzaniem na ich miejsce wyrazów jednoznacznych, ewentualnie o mniejszej liczbie pól semantycznych w porównaniu z XI-wiecznym zabytkiem $(\mathrm{BO}=\mathrm{EJ})$. Dzięki takiemu zabiegowi, kosztem leksykalnej jednorodności tekstów tej samej redakcji, wyraz, a przez

\begin{tabular}{|c|c|c|c|}
\hline EO & $\mathrm{BO}$ & EJ & \\
\hline покровъ & $\Rightarrow \mathbf{c k} \gamma_{д \in A Ы}$ & $\Rightarrow$ скУ & 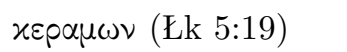 \\
\hline мьния & $\Rightarrow$ юн'ьишїи & $\Rightarrow$ юн'йшїй & 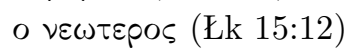 \\
\hline БAAAH & $\Rightarrow \Lambda * a$ & $\Rightarrow \Delta * \mathbf{a}$ & $\lambda$ npos (Łk 24:11) \\
\hline прНАОГЧнСА А & $\Rightarrow$ КАючнСА & $\Rightarrow$ КАюЧнСА & $\varepsilon \lambda \alpha \chi \varepsilon \nu($ Łk 1:9) \\
\hline
\end{tabular}
to i cały tekst, stawał się bardziej zrozumiały ${ }^{13}$, por.:

13 O leksykalnych obocznościach spowodowanych szerokim lub wąskim znaczeniem przytoczonych poniżej zob. Kondratiuk 2003, 516-517. 
рОждєнин нҢА $\Rightarrow$ оүжикы єА $\Rightarrow$ оүжики єА

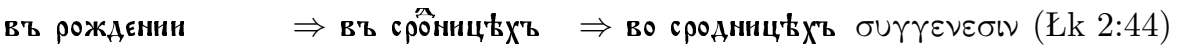

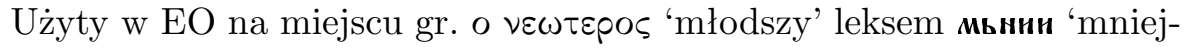
szy według wielkości', 'mniejszy według wieku', 'mniejszy według znaczenia' w obu starodrukach został zastąpiony wyrazem юн'ъишїн $\Rightarrow$ юн'ъйшїй (od юный), który oznacza wyłącznie 'kogoś młodszego'. Dokonanie tej semantycznej zamiany miało dwojakie podłoże. Z jednej strony powstanie oboczności spowodowane było dążeniem do konkretyzacji znaczenia danego leksemu, która z pewnością ułatwiała percepcję czytanego fragmentu, z drugiej dążeniem redaktorów tekstów drukowanych do pełnej zgodności z greckim źródłem (tzw. drugi wpływ południowosłowiański). Interesującym wydają się być dublety рождєнин кєн $\Rightarrow$ оүжикы єА $\Rightarrow$ оүжики єА (Łk 1:58) oraz

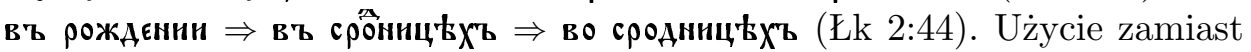
jednego wyrazu greckiego dwóch ekwiwalentnych odpowiedników, pozwala na wyłonienie szeregu synonimicznego ${ }^{14}$ рожАєнин/оүжики/сродники - zјаwiska bardzo charakterystycznego dla szkoły tyrnowskiej. Według L. Lichaczowa

синонимика (...) необходима главным образом потому, что она позволяет выделить оттенки значения [Лихачев 1958, 31].

Co więcej, poprzez użycie w tekście takiej figury, redaktorzy unikali powtórzeń, mogli rozwinąć lub podkreślić myśl wypowiedzi. Leksem рождєнин oznaczający 'zrodzenie', 'płód', 'potomek', 'krewny', 'plemię', 'ród' zarejestrowany w XI-wiecznym EO został zastąpiony w tekstach drukowanych wyrazem оүжики о znacznie węższym polu semantycznym: 'krewny', 'zio-

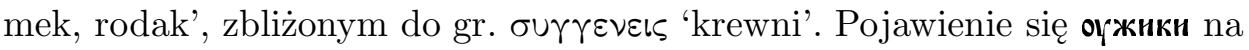
miejscu рождєниє mogło być również spowodowane zawężeniem zakresu semantycznego leksemu рождєнию: w XV w., gdy powstawał pełny przekład Biblii słowiańskiej wyraz ten nie posiadał już znaczenia 'krewni' [Kondratiuk 2003, 516].

$\mathrm{Na}$ uwage zasługuje jeszcze jeden dublet powstały w wyniku eliminacji leksemu wieloznacznego, a mianowicie покровъ $\Rightarrow$ скУАєлы $\Rightarrow$ скУ Аєлы

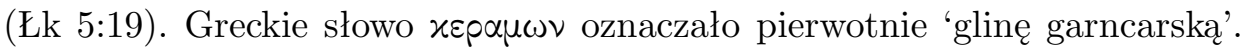
Z biegiem czasu zaczęto go używać na oznaczenie wszystkiego, co było zrobione z gliny, a więc również jako 'pokrycie dachówkowe (dach), dachówka'. W języku słowiańskim jego odpowiednikiem był wieloznaczny wyraz

14 Analiza porównawcza pozwoliła na wyłonienie takich synonimicznych ciągów, jak

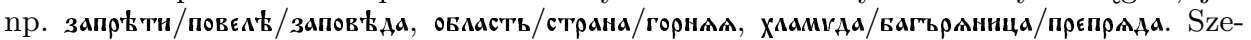
rzej o szeregach synonimicznych w EO i EJ zob. Kondratiuk 2003, 289-300. 
покровъ lub jednostka leksykalna o zdecydowanie mniejszym polu znaczenio-

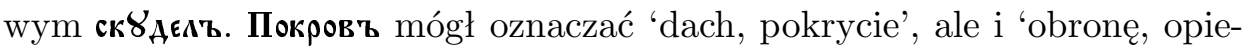
kę, ochronę, ucieczkę', 'zasłonę cerkiewną u królewskich wrót', 'materiał do przykrywania grobu', 'chustę do przykrywania diskosu lub kielicha eucharystycznego' oraz nazwę święta Покровъ Пръсватой Богороднцы (Ofiarowanie Najświętszej Marii Panny). Leksem cкУАєیъ używany był jako 'dachówka, pokrycie z dachówek' lub 'gliniane naczynie'. Jak wynika z przytoczonego poniżej kontekstu, te dwa dublety wystąpiły w znaczeniu 'dach', por.: oв-

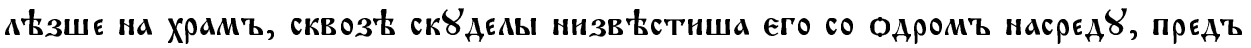
ïrca (EJ, Łk 5:19).

Kolacjonowane teksty rejestrują również sytuację odwrotną, tj. zastępowanie leksemów o wąskim polu semantycznym (EO) wyrazami wieloznacznymi $(\mathrm{BO}=\mathrm{EJ})$, por.:

\begin{tabular}{|c|c|c|c|}
\hline EO & $\mathrm{BO}$ & EJ & \\
\hline дьниюе & $\Rightarrow$ врEMA & $\Rightarrow \mathbf{B} \rho \in M \mathrm{~A}$ & xpovos (Łk 1:57) \\
\hline въскрндин & $\Rightarrow \mathrm{\kappa \rho ad}$ & $\Rightarrow \mathrm{kpaA}$ & 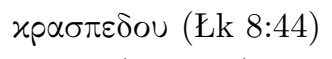 \\
\hline горьнии & $\Rightarrow$ стран' & $\Rightarrow$ стран' & 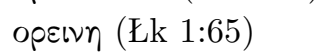 \\
\hline ОБАасти & $\Rightarrow$ страны & $\Rightarrow$ страны & $\pi \varepsilon p l \chi \omega \rho o u($ Łk 8:37) \\
\hline 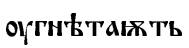 & $\Rightarrow$ ОАРЪЖАТT & $\Rightarrow$ wАЕрЖаTъ & 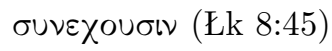 \\
\hline
\end{tabular}

Na uwagę zasługują dwie pary dubletów, tworzących synonimiczny sze-

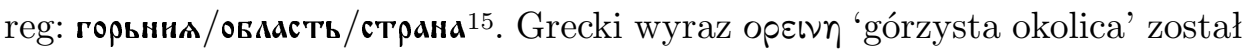
przełożony przez tłumaczy EO jako горьния 'górzysty kraj' i 'podgórze, tj. miejsce znajdujące się u podnóża góry'. Z kolei grecyzm $\pi \varepsilon p \iota \chi \omega \rho o u ~ ' o k o-$ lica, otoczenie' oddany został za pomocą wyrazu овмасть 'władza, panowanie', 'okręg (cerkiewny i państwowy podział ziemi)', 'mieszkańcy okręgu'. W tekstach drukowanych, odpowiednikiem tych dwóch greckich wyrazów jest zawsze страна - leksem о bardzo szerokim polu semantycznym, zawierającym w sobie oba te znaczenia: 'strona, bok', 'brzeg', 'część', 'przeciwnik w walce', 'kraj, ziemia, region', 'naród'.

Z kolei zastąpienie wyrazu oyrn'kтати' 16 , posiadającym znaczenie 'uciskać, tratować', 'napierać', leksemem o wyjątkowo szerokim polu semantycznym шаєржати: 'ogarnąć', 'okrążać', 'opanować', 'panować nad kimś, rządzić', 'więzić w swoich objęciach', 'rozkazywać', 'obejmować', 'zatrzymać, pojmać', mogło być spowodowane z jednej strony chęcią uniknięcia tautolo-

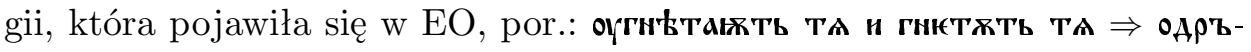

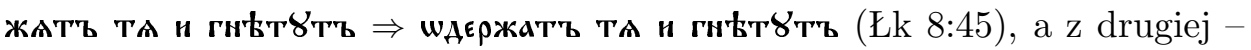

\footnotetext{
15 Zob. Kondratiuk 2003, 519.

16 Zob. także Kondratiuk 2003, 518.
} 
dążeniem do zgodności z greckim oryginałem, który w danym fragmencie również rejestruje dwa różne leksemy: gr. $\sigma u v \varepsilon \chi o \cup \sigma \nu$ 'otaczać, obejmować'

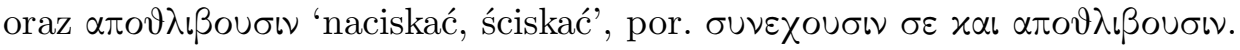

Niekiedy zarejestrowane dublety przybierają charakter zmian merytorycznych. Dość wyraźnie zaznaczone one zostały w następujących parach, por.:

\begin{tabular}{|c|c|c|c|}
\hline $\mathrm{EO}$ & $\mathrm{BO}$ & EJ & \\
\hline на ов & 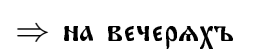 & $\Rightarrow$ МА ВЕЧЕрАХ'Ъ & 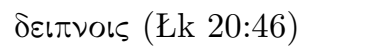 \\
\hline на стьгнахъ & $\Rightarrow$ на распУтїнхъ & $\Rightarrow$ на распУтїнхъ & $\pi \lambda \alpha \tau \varepsilon\llcorner\alpha l \zeta($ Łk 13:26) \\
\hline пвти & $\Rightarrow$ расп४тїА & $\Rightarrow$ расп४тїл & oঠous (Mt 22:10) \\
\hline потопъ & $\Rightarrow \mathrm{BOAA}$ & $\Rightarrow \mathrm{BOAA}$ & $x \alpha \tau \alpha x \lambda \cup \sigma \mu о \varsigma$ (Mt 24:39) \\
\hline ВЪЗБОГАНШа & $\Rightarrow$ въЗАВиГОшА & $\Rightarrow$ возАВиГОша & 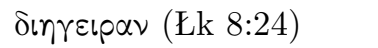 \\
\hline прқгадємъ & $\Rightarrow$ прєндєMъ & $\Rightarrow$ прєй_AєMъ & $\delta เ \varepsilon \lambda \vartheta \omega \mu \varepsilon \nu$ (Łk 8:22) \\
\hline гадхщємъ & $\Rightarrow$ нА Учнмъ & $\Rightarrow$ иA $У \Psi \epsilon м ъ$ & $\pi \lambda \varepsilon о \nu \tau \omega \nu$ ( Łk 8:23) \\
\hline
\end{tabular}

Udokumentowane merytoryczne oboczności między kolacjonowanymi tekstami, tj. między EO a starodrukami, mają charakter różnic indywidualnych, a podjęte próby ich interpretacji mogą nosić charakter tylko hipotetyczny. Jednak głównej przyczyny ich powstania można dopatrywać się przede wszystkim w dążeniu korektorów do wiernego oddania greckiego ory-

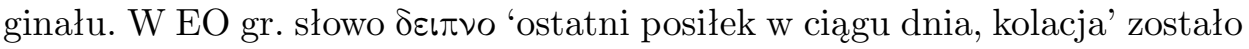

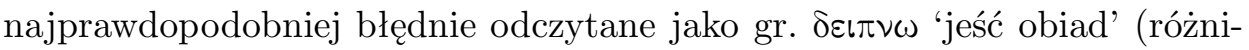
ca dotyczy grafemów o/ $\omega$ ). Stąd XI-wieczny cs. przekład rejestruje leksem ókł_z. Późniejsi redaktorzy w wyniku przeprowadzonej rewizji wprowadzili prawidłowy odpowiednik gr. $\delta \varepsilon เ \pi \nu$ - wyraz вєчєрA. Dążeniem korektorów obu tekstów drukowanych do zgodności z greckim oryginałem wytłumaczyć można również oboczność на стьгнахъ $\Rightarrow$ на расп४тїихъ $\Rightarrow$ на расп४тїихъ (Łk 13:26). Gr. $\pi \lambda \alpha \tau \varepsilon\llcorner\alpha$ 'szeroka droga, szeroka ulica, plac' w starodrukach został oddany za pomocą prawidłowego tłumaczenia pacn४тїє 'szeroka ulica'. Z kolei użyty w EO leksem стьrнa 'ścieżka' należy uznać za błąd merytoryczny, w sposób istotny odbiegający od greckiego wzorca, a przez to zniekształcający prawidłowy odbiór tekstu. W kolejnych trzech dubletach zgodność z greckim oryginałem utrzymuje wyłącznie tekst EO: gr. oঠos 'droga' przybiera formę пкть 'droga', gr. $x \alpha \tau \alpha x \lambda \cup \sigma \mu о \varsigma$ - 'zatopienie, zalanie, potop'17 zo-

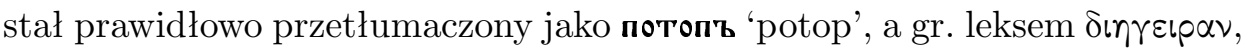

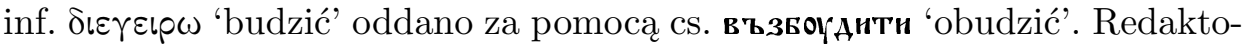
rzy tekstów drukowanych, odchodząc od dokładnego przekładu, wprowadzili

17 Gr. $x \alpha \tau \alpha$ to przyimek oznaczający miejsce, a gr. $\varkappa \lambda \cup \sigma \omega$ znaczy 'zmywać, spłukiwać'. 
do ewangelicznych wypowiedzi poważną nieścisłość, która wpływa na percepcje powyższych perykop, a jednocześnie w pewnym stopniu poświadcza stopień znajomości języka greckiego samych redaktorów.

Na uwagę zasługuje dokonany w BO i EJ przekład dwóch różnych greckich wyrazów: $\pi \lambda \alpha \tau \varepsilon\llcorner\alpha$ 'szeroka droga, szeroka ulica, plac' oraz oós 'droga' za pomocy jednego słowiańskiego pacnชтïє 'szeroka ulica'. Nieuwzględnienie przez redaktorów tej semantycznej różnicy greckich leksemów doprowadziło do powstania niedokładności cs. tłumaczenia, a to z kolei dało początek dwóm obocznościom: на стьгнахъъ $\Rightarrow$ на расп४тїнхъ $\Rightarrow$ на распУтїнхъ (Łk 13:26) oraz пжти $\Rightarrow$ расп४тїі $\Rightarrow$ расп४тї (Mt 22:10).

$\mathrm{Z}$ kolei dwie ostanie merytoryczne zamiany układają się w pewien ciąg, wypływający z całości wypowiedzi, por. $(\mathrm{EO} \Rightarrow \mathrm{BO}=\mathrm{EJ})$ : І быть во єдннъ

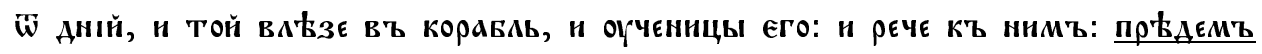
$\Rightarrow$ прєйдємъ (gr. $\delta เ \varepsilon \lambda \vartheta \omega \mu \varepsilon \nu$ 'przejdźmy') па онъполъ езєра. и вънндошА

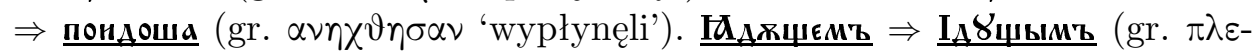

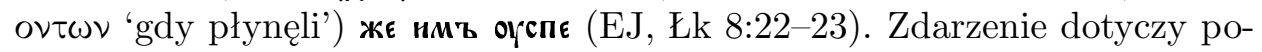
ruszania się łodzią po wodzie. Niekonsekwencja gr. oryginału, zaznaczona poprzez użycie różnych czasowników ruchu ('iść', 'płynąć' - 2 u.), została zastąpiona w obu tekstach drukowanych tylko jednym - 'iść'. Natomiast tekst EO rejestruje w tych miejscach, również niezgodnie z tekstem greckim, czasownik 'jechać' (2 u.) oraz 'wsiąść'. Powyższe oboczności są zatem doskonałym przykładem tego, iż korektorzy cs. tekstów nie zawsze kurczowo trzymali się greckiego oryginału i że przyczyna oboczności merytorycznych nie zawsze leżała po stronie tekstu greckiego. W tym przypadku użycie w starodrukach jednej formy czasownika mogło być spowodowane próbą zachowania konsekwencji, logiczności wypowiedzi lub też uściślenia znaczenia fragmentu tekstu. Dokonana korekta w stosunku do tekstu EO jest świadectwem dobrze rozwiniętej techniki przekładu.

Pojawienie się niektórych dubletów leksykalnych związane jest, z jednej strony, z przemianami semantycznymi słownictwa istniejącego już w zasobach słownictwa scs. i wykształceniem się nowych, wtórnych znaczeń (por. wyżej), z drugiej - użyciem przez korektorów wyrazów nowszych, będących poza tym zasobem. Młodsze elementy słownikowe zostały zarejestrowane w BO i EJ, por.:

\begin{tabular}{|c|c|c|c|}
\hline EO & $\mathrm{BO}$ & EJ & \\
\hline AревAIF & $\Rightarrow$ прє⿻コ一火⿷ & $\Rightarrow$ прєसA & 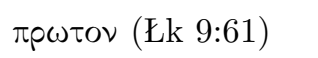 \\
\hline И10ДEИ & $\Rightarrow$ ЖНАОВЕ & $\Rightarrow$ ЖHАOBE & เouס̊เoเ (J 1:19) \\
\hline кажєници & $\Rightarrow$ скопцы & $\Rightarrow$ скопцы & Euvouxor (Mt 19:12) \\
\hline Съ свЊТтиььникы & $\Rightarrow$ съ свьтины & $\Rightarrow$ со свЊтилы & $\mu \varepsilon \tau \alpha \varphi \alpha \nu \omega \nu$ (J 18:3) \\
\hline
\end{tabular}


Geneza tych leksemów, charakterystycznych dla młodszych tekstów cs., często pozostaje niejasna, a ich zasięg geograficzny trudny do wytyczenia [Friedelówna 1974, 215]. Jednak oba typy dubletów stanowią o przynależności tekstów drukowanych do zabytków młodszej klasy. Analiza porównawcza trzech tekstów pozwoliła również na wyłonienie sytuacji odwrotnej, tj. dubletów, w których na miejscu wyrazu młodego w EO pojawia się w starodrukach wyraz starszy, por.:
EO
$\mathrm{BO}$
EJ
огжасостасA
$\Rightarrow$ днвистасА
$\Rightarrow$ днвнстасА
$\varepsilon \xi \varepsilon \sigma \tau \eta \sigma \alpha \nu($ Łk 8:56)
ontkBsix
$\Rightarrow$ ow8ror
$\Rightarrow$ wwלtoro
$\varepsilon \cup \omega \nu \cup \mu \omega \nu(\mathrm{Mk} 10: 40)$

Pierwotność wyrazu шюи nad львыи potwierdzają językowe fakty przytoczone przez A. S. Lwowa [Львов 1966, 269-272]. Leksem 九 ввица wszedł do użyciu już w XI w., jednak przede wszystkim w tekstach wschodniobułgarskiej redakcji. Stąd jego obecność w XI-wiecznym EO, który został spisany z oryginału przywiezionego właśnie ze wschodniej Bułgarii. Przyczyną zastąpienia wyrazu шюи leksemem к қвын był fakt, iż wyraz шюи między X a XV w. zatracił swoje ogólnosłowiańskie znaczenie i zaczął być odbierany jako dialektyzm [Львов 1966, 271]. W starodrukach pojawił się ponownie, najprawdopodobniej w wyniku tzw. drugiego wpływu południowosłowiańskiego, kiedy to nastąpiła archaizacja języka i zwrócenie się ku leksyce pierwotnej, rzadko używanej nawet w scs. tekstach.

Przynależność trzech ewangelicznych tekstów do cs. tradycji piśmienniczej redakcji ruskiej z definicji wymaga obecności w nich ruskich elementów leksykalnych. Jednak tzw. drugi wpływ południowosłowiański, który przyniósł grecyzację i archaizację języka, starał się wszelkimi sposobami wyeliminować słownictwo rodzime. Kontaminacja tekstów miała na celu ekscerpcję wyłącznie oboczności. Obecność leksyki potocznej, występującej paralelnie we wszystkich tekstach, nie była przedmiotem niniejszej analizy.

\begin{tabular}{|c|c|c|c|}
\hline $\mathrm{EO}$ & $\mathrm{BO}$ & EJ & \\
\hline кровы & $\Rightarrow$ сьни & $\Rightarrow$ сьни & oxnvas (Mt 17:4) \\
\hline 6081 & $\Rightarrow$ оїродив & $\Rightarrow$ оїродив & $\mu \omega \rho \omega$ (Mt 7:26) \\
\hline TьAI & $\Rightarrow$ момь & $\Rightarrow$ моAь & ons (Łk 12:33) \\
\hline $\overrightarrow{\mathrm{r}} \mathrm{b}$ домог & 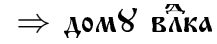 & $\Rightarrow{ }_{\text {AОMУ BÂKa }}$ & 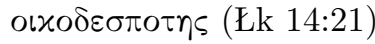 \\
\hline книгамъ & $\Rightarrow$ писанїю & $\Rightarrow$ писанїю & rpapn (J 2:22) \\
\hline
\end{tabular}

Wśród dubletów zawierających jeden człon o wschodniosłowiańskiej (ruskiej) proweniencji, na uwagę zasługuje leksykalna oboczność тыма

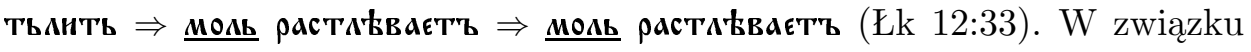


z tym, że żaden słownik zachodnich ani południowych Słowian nie rejestruje leksemu тьмra (gr. ons), A. S. Lwow wychodzi z założenia, iż rzeczownik ten powstał od słowiańskiego czasownika тым'ти 'gnić, ulegać rozkładowi' (tak jak капмra od капати сzy вомra od вєлłти). Stąd obecność formacji czasownikowej we wszystkich kolacjonowanych cs. tekstach redakcji

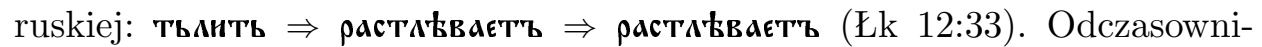
kowy rzeczownik тымra oznaczał 'zgniliznę, zepsucie'. Dlatego w scs. tekstach w znaczeniu greckiego słowa ons 'mól' nigdy nie został on zarejestrowany samodzielnie ${ }^{18}$, a zawsze $\mathrm{w}$ stałym połączeniu тьма тьмить, od-

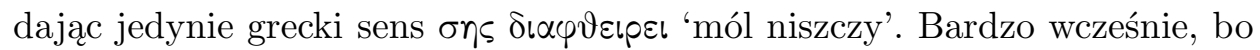
najprawdopodobniej już w X-XI w. leksem тьмra wyszedł z użycia, a jego miejsce zajął najpierw słowiański wyraz чєрвь, a później моль [Львов 1966, 245-247].

Sytuacja odwrotna, tj. zastąpienie elementu ruskiego poświadczonego w EO leksemem scs., została zarejestrowana tylko dwukrotnie, por.:

\begin{tabular}{|c|c|c|c|}
\hline EO & $\mathrm{BO}$ & EJ & \\
\hline & $\Rightarrow$ нӒ̈нородный & $\Rightarrow \epsilon_{A}$ ннородный & novorevns (J 1:18) \\
\hline 10T' & $\Rightarrow$ ropt & $\Rightarrow$ ropk & oval (Mt 26:24) \\
\hline
\end{tabular}

\section{2. leksem grecki $(\mathrm{EO}) \Rightarrow$ leksem słowiański $(\mathrm{BO}=\mathrm{EJ})$}

W cs. tekstach drukowanych w konfrontacji z językiem EO zarysowuje się tendencja do zastępowania elementów greckich wyrazami słowiańskimi (przede wszystkim wschodniosłowiańskimi, niekiedy wschodniobułgarskimi i zachodniobułgarskimi). Zjawisko to jest z pewnością znacznie szersze niż przeciwstawna mu grecyzacja języka tekstów drukowanych (zob. par. 1.4.), por.:

\begin{tabular}{|c|c|c|c|}
\hline EO & $\mathrm{BO}$ & EJ & \\
\hline 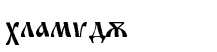 & $\Rightarrow$ БаГРАнНЦУ & $\Rightarrow$ БаГрАннцУ & $\chi \lambda \alpha \mu \nu \cup \delta \alpha($ Mt 27:31) \\
\hline $\operatorname{anA} \mathbf{A}$ & $\Rightarrow$ посланникъ & $\Rightarrow$ посланникъ & $\alpha \pi \circ \sigma \tau о \lambda \circ \varsigma$ (J 13:16) \\
\hline параскеуги & $\Rightarrow$ пАтокъ & $\Rightarrow$ пАтокъ & 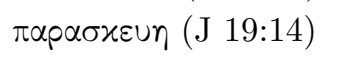 \\
\hline параканть & $\Rightarrow$ оїТкЕшитєАь & $\Rightarrow$ оїткшитекь & $\pi \alpha \rho \alpha \lambda \lambda \eta \tau$ то (J 15:26) \\
\hline на с४коморинж & $\Rightarrow$ НА гаГОАНЧнНУ & $\Rightarrow$ на гагодичинУ & 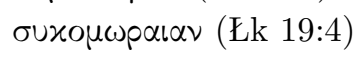 \\
\hline скинопигна & $\Rightarrow$ потЪ Чєниє сСНн & $\Rightarrow$ ПОТЧЕНїє с-Кни & 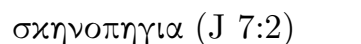 \\
\hline
\end{tabular}

18 Gr. ons 'mól' oddawany był zazwyczaj w cs. tekstach za pomocą słowiańskiego sło-

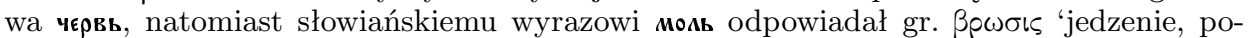
karm; rdza lub wszelkie inne sposoby strawienia nagromadzonych dóbr, ewentualnie rodzaj szkodnika' (np. Mt 6:19). 


\begin{tabular}{|c|c|c|c|}
\hline краникво мћсто & $\Rightarrow$ МОБНОЕ МҺСТО & $\Rightarrow$ МОБНОЕ МКСТО & 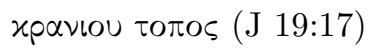 \\
\hline 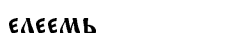 & $\Rightarrow$ масломъ & $\Rightarrow$ масломъ & $\varepsilon \lambda \alpha \iota \omega(\mathrm{Mk} 6: 13)$ \\
\hline катапєТАЗма & $\Rightarrow 3 \mathrm{ABtca}$ & $\Rightarrow 3 \mathrm{ABkca}$ & $\varkappa \alpha \tau \alpha \pi \varepsilon \tau \alpha \sigma \mu \alpha($ Mt 27:51) \\
\hline vпокрити & $\Rightarrow$ хнцємћри & $\Rightarrow$ мнцємЊри & 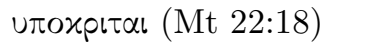 \\
\hline HюАЕН & $\Rightarrow$ ЖНАОВЕ & $\Rightarrow$ ЖHАОВE & 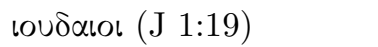 \\
\hline
\end{tabular}

Nie znaczy to, że ze starodruków całkowicie zostały wyeliminowane wyrazy o greckiej proweniencji. Oprócz „oswojonych” [Верещагин, Крысько

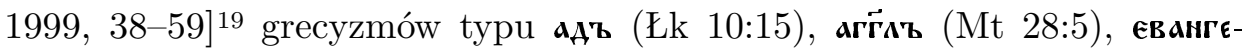
๙ï (Mk 1:15), teksty drukowane rejestrują wyrazy greckie, często występujące $\mathrm{w}$ koegzystencji ze słowiańskimi tłumaczeniami, por.: gr. xpavıo

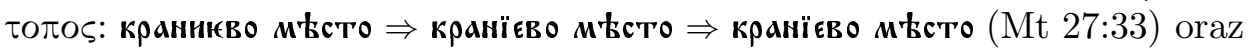

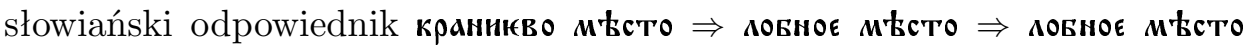

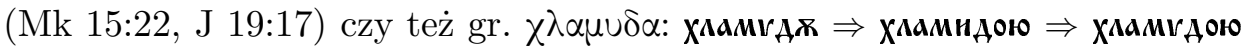
(Mt 27:28) oraz ХАамгад $\Rightarrow$ БагрАниц $\Rightarrow$ БагрАниц (Mt 27:31). Grecyzmy do tekstu zostały wprowadzone przez samych św. św. Cyryla i Metodego. Jednak ich dobór, jak pokazują badania, nie był kwestą przypadku. Bez przekładu zostały pozostawione przede wszystkim: imiona własne osobowe i miejscowe; nazwy narodów, ugrupowań; zapożyczenia leksykalne, które przeniknęły do narzecza sołuńskiego jeszcze przed misją morawską; wyrazy wprowadzone przez św. Cyryla pod wpływem kontekstu, zawierającego glosy lub zmuszającego tłumacza do zachowania cytatu. Oddzielną grupę stanowiły grecyzmy, które już w Septuagincie były obcymi zapożyczeniami [Moszyński 1969, 552-564]. Za takie uznać należy hebraizmy oraz pożyczki przejęte z języka łacińskiego.

\section{3. leksem obcy, inny niż grecki $(\mathrm{EO}) \Rightarrow$ leksem słowiański $(\mathrm{BO}=\mathrm{EJ})$}

Pod pojęciem leksyki obcej kryją się wyrazy hebrajskie i łacińskie, które w tekście Septuaginty odbierane były jako zapożyczenia. W związku z tym, iż św. Cyryl doskonale znał język hebrajski, z łatwością mógł odróżnić słowa pochodzenia hebrajskiego Septuaginty od wyrazów greckich. Zasada, którą przyjął w odniesieniu do tych leksemów polegała na zachowaniu ich w tekście Ewangelii bez zmian. Greckie pośrednictwo odbiło się wyłącznie na postaci fonetycznej scs. hebraizmów [Moszyński 1969, 552-564]. Reguła ta była przestrzegana również przez kolejnych redaktorów, czego dowodem są zapi-

19 L. Moszyński przyjmuje, iż takie terminy chrześcijańskie były zadomowione już w narzeczu sołuńskim. Św. Cyryl używając ich, wprowadzał wprawdzie grecyzmy, ale przyswojone przez Słowian [Moszyński 1969, 552-564]. 
sy typu пасха (Mt 26:2), мєсига $\Rightarrow$ мєсїа $\Rightarrow$ мєсига (J 4:25), амннь (Mk 8:12), манн (J 6:58) we wszystkich trzech kolacjonowanych tekstach.

Szczególną grupą stanowią latynizmy związane z władzą rzymską w Palestynie. One też zostały pozostawione bez tłumaczenia przez samego św. Cyryla [Moszyński 1969, 552-564]. Również w kolacjonowanych cs. tekstach ruskiej redakcji w większości poświadczeń nie poddały się one przekładowi, por.:

\begin{tabular}{|c|c|c|c|}
\hline $\mathrm{EO}$ & $\mathrm{BO}$ & EJ & \\
\hline КО人стТАДНА & $\Rightarrow$ к४стодїа & $\Rightarrow \kappa 8 \mathrm{c} T w_{A} \bar{A} \mathrm{~A}$ & 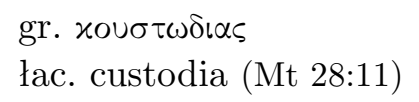 \\
\hline кин'съ & $\Rightarrow$ кинсонъ & $\Rightarrow$ кинсонъ & $\begin{array}{l}\text { gr. xnvбov } \\
\text { łac. census (Mt 1:25) }\end{array}$ \\
\hline кєсара & $\Rightarrow \kappa \in \mathrm{cap} \boldsymbol{\Lambda}$ & $\Rightarrow$ кє⿻二丨 & $\begin{array}{l}\text { gr. xalбapos } \\
\text { łac. Caesar (Łk 2:1) }\end{array}$ \\
\hline прєторъ & $\Rightarrow$ прєторъ & $\Rightarrow$ прєтшръ & 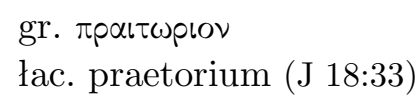 \\
\hline кентоҮрнона & $\Rightarrow$ сотьннка & $\Rightarrow$ сотника & 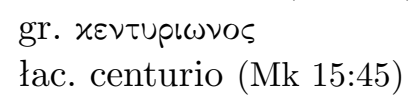 \\
\hline спира & $\Rightarrow$ спира & $\Rightarrow$ спнра & $\begin{array}{l}\text { gr. } \sigma \pi \varepsilon ı \rho \alpha \nu \\
\text { łac. cohors (J 18:12) }\end{array}$ \\
\hline
\end{tabular}

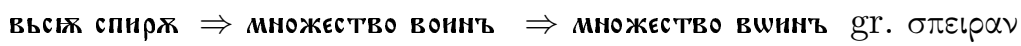

łac. cohors (Mt 27:27)

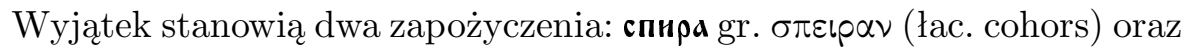

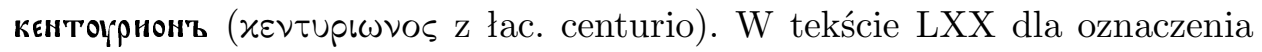

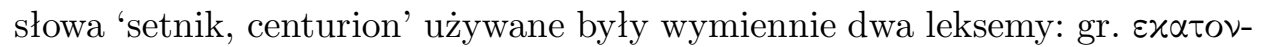

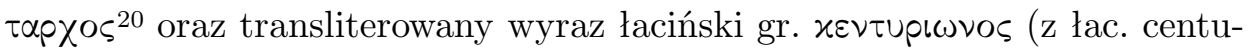
rio). Ich użycie uzależnione było od autora Ewangelii: św. Mateusz i św. Łukasz używali grecyzmu, natomiast św. Marek - formacji łacińskiej. Podobny podział ukształtował się w scs. piśmiennictwie. Zgodnie z nim, przejęte

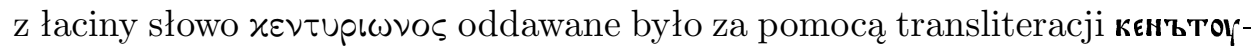

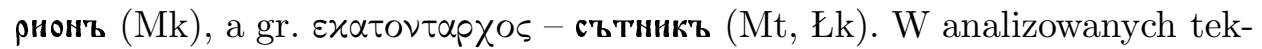

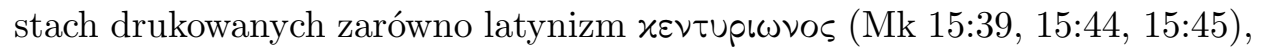

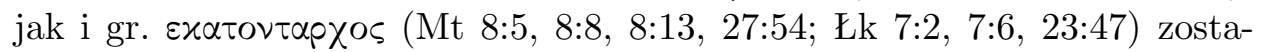
ły zapisane wyłącznie jako сотникъ. Zastąpieniu słowa кєнътоүрионъ słoшеm сотникъ sprzyjała najprawdopodobniej niejednolitość tekstu greckiego

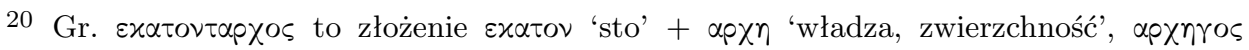
'wódz'. 


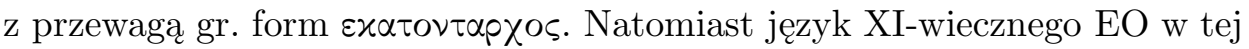
kwestii rejestruje wahania. Podczas gdy wszystkie gr. leksemy $\varepsilon x \alpha \tau o \nu \tau \alpha \rho \chi o \varsigma$ oddane zostały za pomocą słowa сотникъ (pod tym względem przekład jest

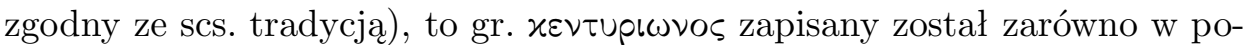
staci кенътогрнонъ ( $1 \mathrm{u}$. Mk 15:45), jak і сотникъ (3 u. Mk 15:44 2x, 15:45), co może świadczyć o rozpoczętym, ale nie zakończonym, jak w tekstach drukowanych, procesie wymiany latynizmu na grecką kalkę.

Natomiast łacińska nazwy rzymskiej jednostki wojskowej łac. cohors została w tekście Septuaginty zastąpiona przez rodzimy dla Greków odpo-

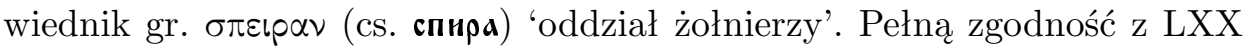
prezentuje tekst EO. Natomiast w tekstach drukowanych gr. $\sigma \pi \varepsilon ı \rho \alpha \nu ~ z a p i s a-$ ne zostało zarówno w transliteracji спнра (3 u.: Mk 15:16, J 18:3, J 18:12), jak i w postaci rodzimej множєство воннъ $\Rightarrow$ множєство вшинъ (1 u.: Mt 27:27).

\section{4. leksem słowiański $(\mathrm{EO}) \Rightarrow$ leksem grecki $(\mathrm{BO}=\mathrm{EJ})$}

Cs. teksty drukowane redakcji ruskiej, pomimo funkcjonowania w starszych tekstach ich słowiańskich odpowiedników, wprowadzają do przekładu wiele wtórnych grecyzmów. Niewątpliwie, w poniższych dubletach odzwierciedlony został tzw. drugi wpływ południowosłowiański, którego celem była maksymalna grecyzacja języka $(\mathrm{BO}=\mathrm{EJ})$ poprzez m.in. wyeliminowanie z niego elementów rodzimych (EO), por.:

\begin{tabular}{|c|c|c|c|}
\hline $\mathrm{EO}$ & $\mathrm{BO}$ & EJ & \\
\hline МЕЧЬНнКА & $\Rightarrow$ спєкУАатора & $\Rightarrow$ спєкУАатора & $\sigma \pi \varepsilon \varkappa o \cup \lambda \alpha \tau \omega \rho \alpha(\mathrm{Mk} 6: 27)$ \\
\hline когръ & $\Rightarrow$ алєКТТОрЪ & 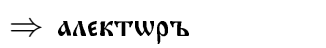 & $\alpha \lambda \varepsilon \varkappa \tau \omega \rho$ (Mt 26:34) \\
\hline ОцьТЬно вино & $\Rightarrow$ єсмнрнисмєно вино & $\Rightarrow$ єсмУрнїсмено вино & $\varepsilon \sigma \mu \cup \rho \nu เ \sigma \mu \varepsilon \nu \circ \nu$ (Mk 15:23) \\
\hline АатиньскЫ & $\Rightarrow$ рнмски & $\Rightarrow$ рнмски & $\rho \omega \mu \alpha \iota \sigma \tau \iota(J$ 19:20) \\
\hline
\end{tabular}

\section{Leksyka EO i BO jest zbieżna $(\mathrm{EO}=\mathrm{BO})$, ale niezgodna $\mathrm{z}$ EJ}

Materiał egzemplifikacyjny ilustrujący różnice między $\mathrm{EO}=\mathrm{BO}$ a $\mathrm{EJ}$ jest znikomy, bo poparty tylko jednym przykładem, por.:
EO
$\mathrm{BO}$
EJ
прнде
$\Rightarrow$ прїнде
$\Rightarrow$ приступи
$\eta \lambda \vartheta \varepsilon \nu(€ \mathrm{k} \mathrm{8:41)}$

Powstała oboczność sprowadza się do płaszczyzny stylistycznej: neutralny leksem pride został zastąpiony w EJ przez wyraz nacechowany. 


\section{Leksyka EO i EJ jest zbieżna $(\mathrm{EO}=\mathrm{EJ})$, ale niezgodna $\mathrm{z} \mathrm{BO}$}

Powyższą grupę również stanowią nieliczne oboczności leksykalne, por.: EO $\mathrm{BO}$ EJ

HAM наставьници

$$
\begin{array}{ll}
\Rightarrow \text { ГРААН } & \Rightarrow \text { нАН } \\
\Rightarrow \text { оїчнТЕАЕ } & \Rightarrow \text { НаставнНЦЫ }
\end{array}
$$

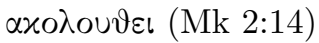

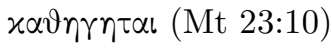

Powstanie oboczności w obrębie wyrazów o synonimicznym znaczeniu

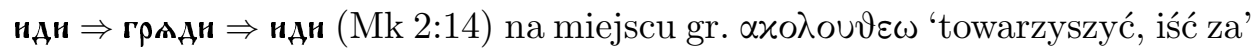
spowodowane było względami stylistycznymi: wyraz neutralny nди 'iść', odzwierciedlający tekst oryginału, a zarejestrowany w EO i EJ, zastąpiony został w BO elementem o większej sile ekspresji грлди 'podążać'. Podobnie jest w przypadku oboczności наставьннци $\Rightarrow$ оүччнтєлє $\Rightarrow$ наставницы (Mt 23:10) gr. $x \alpha \vartheta \eta \gamma \eta \tau \eta s ~ ' p r z e w o d n i k$, profesor, mistrz', z tą różnicą, że jednostce nacechowanej stylistycznie użytej w EO i ЕJ наставникъ, zgodnej z tekstem greckim, odpowiada w BO element neutralny оүччитекь. W tym przypadku użycie elementu nacechowanego stylistycznie nadało tekstowi cech podniosłości, która charakteryzowała grecki oryginał ${ }^{21}$. Zastosowane w EO i EJ leksemy nie są więc kwestią przypadku, a raczej efektem świadomego redagowania tekstu opartego na tekście greckim. Stąd stylistyczną zgodność z tekstem greckim zachowuje wyłącznie tekst EO i EJ.

Przeprowadzona analiza pokazuje, iż większość z wyodrębnionych par istnieje na zasadzie zamiany jednego słowiańskiego wyrazu drugim, także słowiańskim, przy czym odpowiednikiem tych dwóch wyrazów słowiańskich jest z reguły jeden wyraz grecki. Liczną grupę stanowią również pary, w których leksem słowiański został zastąpiony w którymś z tekstów korelatem obcym (zazwyczaj greckim) lub szeregi, w których na miejscu wyrazu obcego odnajdujemy jego słowiański odpowiednik. Dodatkowo, oprócz zarejestrowanych rozbieżności w obrębie trzech cs. tekstów, każdy z nich z osobna posiada własną, wewnętrzną wariantywność (tzw. synonimy wewnętrzne): gr. $\alpha \lambda \varepsilon x \tau \omega \rho$ pozostawione zostało albo bez tłumaczenia w postaci axєא-

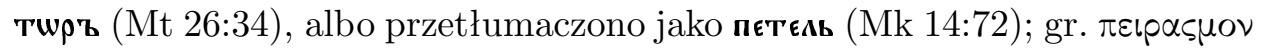
odpowiada cs. во искУшєнїє (Łk 11:4) оraz въ напасть (Mt 6:13); na miej-

\footnotetext{
21 Niektórzy filolodzy uważają, iż autorzy Pisma Świętego nie stosowali specjalnej stylizacji, lecz jej styl odpowiadał ówczesnemu językowi i nie różnił się od stylu równolegle powstających tekstów hebrajskich. To kolejni tłumacze i redaktorzy starając się zachować wierność tekstowi, w istocie zatracili wierność stylu, zmieniając naturalny styl oryginału w sztucznie podniosły styl przekładu [Piela 2003, 13].
} 


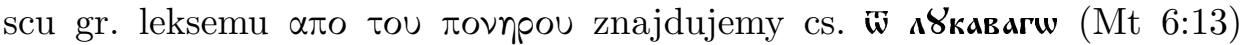

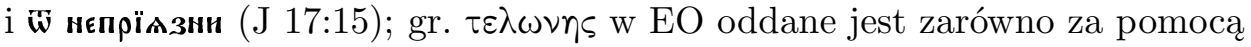
мьздонмьць (Łk 18:13), jak і мытарь (Mt 18:17), itp. Korektorzy poddanych analizie tekstów nie podjęli wysiłku konsekwentnej unifikacji zapisu tych bliskoznacznych wyrazów na korzyść jednego wariantu leksykalnego, być może dlatego, iż autorzy tłumaczenia ksiąg biblijnych synonimami posługiwali się celu

избежать повторения одних и тех же слов, чтобы подчеркнуть ту или иную сторону значения, выделить в синонимах семантические различия [Лихачев 1958, 31].

Późniejsi redaktorzy mając do wyboru przynajmniej dwa warianty dla oddania jednego wyrazu greckiego, nie zawsze wybierali ten sam, co ich poprzednicy [Szulc 2000, 64].

Niekiedy brak ujednolicenia tekstu mógł być spowodowany chęcią uniknięcia $\mathrm{w}$ jednym wersecie powtórzenia, jak w przypadku gr. leksemu $\alpha \lambda \varepsilon x-$ $\tau \omega \rho$, zapisanego w BO i EJ jako алєкторъ $\Rightarrow$ алєктшръ (Mt 26:34, Mk 14:68, Mk 14:72, J 13:38) oraz jeden raz, również w perykopie Mk 14:72, jako

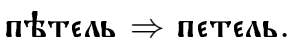

Przeprowadzona analiza porównawcza zgromadzonego materiału kolacjonowanych cs. tekstów pozwala na sformułowanie ogólniejszej konkluzji na temat zmian w zasobie leksykalnym języka cs. ruskiej redakcji. Te przemiany dokonały się na przestrzeni kilku stuleci, dlatego stanowią świadectwo powolnej ewolucji języka.

Bogaty materiał odróżniający słownictwo EO od słownictwa BO i EJ $(\mathrm{EJ}=\mathrm{BO})$, poświadcza ogromne zróżnicowanie leksyki aprakosów krótkich (EO) i tetr liturgicznych (EJ), oraz zbieżnych z nim wydań pełnej Biblii nie przeznaczonej do celów liturgicznych (BO, tzw. четьий текст). Z kolei leksyka EJ w zestawieniu z pierwszą wydrukowaną w Ostrogu Biblią słowiańską z wyjątkiem trzech poświadczeń [EO прндє $\Rightarrow \underline{\mathrm{BO}}$ прїндє $\Rightarrow$ ЕJ прнст8Пи (Łk 8:41), иди $\Rightarrow$ Гради $\Rightarrow$ иди (Mk 2:14), наставьници $\Rightarrow$ оүччителє $\Rightarrow$ наставницы (Mt 23:10)] jest dowodem wielkiego pokrewieństwa obu tekstów. Na podstawie nielicznych i mało znaczących rozbieżności obu starodruków z pełną odpowiedzialnością można stwierdzić, iż XVIII-wieczny czteroewangeliarz liturgiczny zachował przednikonowską leksykę w stanie praktycznie nienaruszonym. Przeprowadzane reformy ${ }^{22}$,

22 Rewizje ksiąg w czasach patriarchy Filareta (1919-1640), patriarchy Józefa (16421652), patriarchy Nikona (1652-1658), patriarchy Joachima (1674-1690). 
zwieńczone ostatecznie wydaniem Biblii Elżbietańskiej, nie naruszyły sfery słownictwa tekstów liturgicznych. Nie należy jednak zapominać o licznych rozbieżnościach natury fonetyczno-graficzno-morfologicznejej ${ }^{23}$. Dlatego też dalsze badania nad leksyką tekstów drukowanych powinny objąć również język Biblii Elżbietańskiej.

Kontaminacja trzech ewangelicznych tekstów pozwoliła na wyodrębnienie kilku warstw językowych, jakie złożyły się na jego powstanie. Analiza porównawcza wykazała, że obok leksyki wprowadzonej jeszcze na Morawach i w Panonii (EО пастоүси, мьздонмьць, годнна; ВО=ЕЈ животъ, пропн४тъ), w bliskim sąsiedztwie funkcjonuje leksyka zachodniobułgarska (wyrazy macedońskie), wschodniobułgarska (bułgaryzmy), wschodniosłowiańska (rutenizmy), jak i liczne grecyzmy. Taka różnorodność jest związana z tym, iż od czasu powstania pierwszych słowiańskich przekładów, w wyniku częstego ich kopiowania i redagowania, teksty ewangeliczne za każdym razem wchłaniały pewne elementy uboczne.

Pojawienie się różnorodnych dubletów leksykalnych miało kilka przyczyn. Niewątpliwie duże piętno odcisnęły zmiany semantyczne, jakim na przestrzeni wieków uległo samo słownictwo. Nie bez znaczenia okazały się zmiany stylistyczne, jak i kolejne rewizje greckiego oryginału. Ta największa reforma dokonała się w XIV w. wyniku tzw. drugiego wpływu południowosłowiańskiego, kiedy to określono nowe zasady decydujące o doborze środków leksykalnych.

\section{Teksty źródłowe}

Ostromirovo evangelie 1056-57 goda s priloženiem grečeskago teksta evangelij i s grammatičeskimi ob"âsneniâmi, Sanktpeterburg, [в:] Aitzetmuller R., Matl J., Sandik L., 1964, A. Vostokov, 1843, Evangelium Ostromiri (unverandter nachdruck), Weisbaden. [Остромирово евангелие 1056-57 года с приложением греческаго текста евангелий и с грамматическими объяснениями, Sanktpeterburg, [w:] Aitzetmuller R., Matl J., Sandik L., 1964, A. Vostokov, 1843, Evangelium Ostromiri (unverandter nachdruck), Weisbaden.]

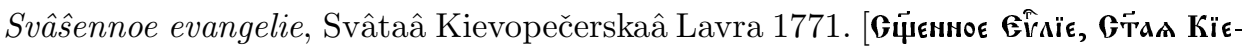
вопєчєрскал Павра 1771.]

Biblâ sireč knigy vethago i novago zaveta, po âzyku slovensku, Ostrog 1581. [Біваїа сирьч книгы вєтХаго и новаго зав'Тта, по газыкУ смовєнскУ, Острогъ 1581.]

23 Zob. Kurianowicz 2015. 


\section{Słowniki}

Ewangeliczny Przektad Interlinearny Biblii, [online], http://biblia.oblubienica.eu [12.10.2017].

Popowski R., ksiądz, 2006, Wielki słownik grecko-polski Nowego Testamentu. Wydanie z petna lokalizacja greckich haset, kluczem polsko-greckim oraz indeksem form czasownikowych, Warszawa.

Sreznevskij I.I., 1958, Materialy dlâ slovarâ drevnerusskogo âzyka, Moskva. [Cpe3невский И.И., 1958, Материаль для словаря древнерусского языка, Москва.]

Vasmer M., 1984, Ètimologičeskij slovar' russkogo âzyka: v 4 tomah, Moskva. [Bacмер М., 1984, Этимологический словарь русского языка: в 4 томах, Москва.]

\section{Literatura}

Dąbek-Wirgowa T., 1980, Historia literatury bułgarskiej. Zarys, Wrocław-Warszawa-Kraków-Gdańsk.

Friedelówna T., 1974, Ewangeliarz Eawryszewski. Monografia zabytku, Wrocław-Warszawa-Kraków-Gdańsk.

Kondratiuk M., 2003, Leksykalne osobliwości języka Ewangeliarza Jabłeczyńskiego - dublety leksykalne, [w:] Chrześcijańskie dziedzictwo duchowe narodów słowiańskich, pod red. Z. Abramowicz, Białystok, s. 513-526.

Kurianowicz M., 2015, Język cerkiewnosłowiański ruskiej redakcji drukowanych przektadów Dobrej Nowiny. Fonetyka, fleksja imienna i werbalna, Białystok.

Moszyński L., 1969, Kryteria stosowane przez Konstantego-Cyryla przy wprowadzaniu wyrazów obcego pochodzenia do tekstów stowiańskich, „Slavia”, T. XXVIII/4, s. 552-564.

Ostapczuk J., 2010, Cerkiewnosłowiański przektad liturgicznych perykop okresu paschalnego i święta Pięćdziesiatnicy w rękopiśmiennych ewangeliarzach krótkich, Warszawa.

Piela M., 2003, Grzech dosłowności we wspótczesnych polskich przekładach Starego Testamentu, Kraków.

Rusek J., 1984, Studia z historii stownictwa butgarskiego, Monografie slawistyczne 46, Wrocław-Warszawa-Kraków-Gdańsk.

Szulc A., 2000, Leksykalne i słowotwórcze zróżnicowanie cerkiewnostowiańskich psatterzy redakcji ruskiej z XI-XIX wieku. Czesść I. Zróżnicowanie leksykalne, Toruń.

Alekseev A.A., 1999, Tekstologiâ slavânskoj Biblii, Sankt-Peterburg. [Алексеев А.А., 1999, Текстология славянской Библии, Санкт-Петербург.]

Vereŝagin E.M., 1971, Iz istorii vozniknoveniâ pervogo literaturnogo âzyka slavân. Perevodčeskâ̂ tehnika Kirilla i Mefodiâ, Moskva. [Верещагин E.M., 1971, Из истории возникновения первого литературного языка славян. Переводческая техника Кирилла и Мефодия, Москва.] 
Vereŝagin E.M., Krys'ko V. B., 1999, Nablûdeniâ nad âzykom i tekstom arhaičnogo istočnika - Il'inoj knigi, „Voprosy Âykoznaniâ”, № 3, s. 38-59. [Верещагин Е.М., Крысько В.Б., 1999, Наблюдения над языком и текстом архаичного источника - Ильиной книги, "Вопросы Яыкознания", № 3, c. $38-59$.]

Žukovskaâ L.P., 1976, Tekstologiâ i âzyk drevnejših slavânskih pamâtnikov, Moskva. [Жуковская Л.П., 1976, Текстология и язык древнейших славянских памятников, Москва.]

Kamčatnov A.M., 1998, Istoriâ i germenevtika slavânskoj Biblii, Moskva. [Камчатнов А.М., 1998, История и герменевтика славянской Библии, Москва.]

Lihačev A.D., 1958, Nekotorye zadači izučeniâ «vtorogo ûžnoslavânskogo vliâniầ» $v$ Rossii, Moskva. [Лихачев А.Д., 1958, Некоторье задачи изучения «второго южнославянского влияния» в России, Москва.]

Logačev K.I., 1976, O âzyke i tekste originalov drevnejših slavânskih perevodov, „Voprosy Âzykoznaniâ", № 2, s. 94-99. [Логачев К.И., 1976, О языке и тексте оригиналов древнейших славянских переводов, "Вопросы Языкознания", № 2, с. 94-99.]

Logačev K.I., 1988, Kirillo-mefodievskie perevody u ûžnyh $i$ vostočnyh slavân, Leningrad. [Логачев К.И., 1988, Кирилло-мефодиевские переводы уюжных и восточных славян, Ленинград.]

L'vov A.C., 1974, Var'irovanie sredstv vyraženiâv pamâtnikah staroslavânskoj pis'mennosti, „Voprosy Âzykoznaniâ”, № 6, s. 78-90. [Львов А.Ц., 1974, Варьирование средств выражения в памятниках старославянской письменности, "Вопросы Языкознания", № 6, с. 78-90.]

L'vov A.S., 1966, Očerki po leksike pamâtnikov staroslavânskoj pis'mennosti, Moskva. [Львов А.С., 1966, Очерки по лексике памятников старославянской письменности, Москва.]

Lûdogovskij F.B., 2005, Slavânskâ̂ Bibliâ èpohi knigopečataniâ: problema stabil'nosti teksta i âzyka, [v:] Cerkovnoslavânskij âzyk. Istoriâ, nasledovanie, prepodavanie. Materialy I Meždunarodnoj Naučnoj konferencii (28-30 sentâbrâ 2004 g.), Moskva, s. 130-135. [Людоговский Ф.Б., 2005, Славянская Библия эпохи книгопечатания: проблема стабильности текста и язы$\kappa a$, [в:] Церковнославянский язык. История, наследование, преподавание. Материаль I Международной Научной конференции (28-30 сентября 2004 г.), Москва, с. 130-135.]

Lûdogovskij F.B., 2006, Funkcionirovaniei èvolûciâ služebnogo i čet'ego variantov cerkovnoslavânskogo Evangeliâ v èpohu knigopečataniâ: postanovka problemy, [v:] Lingvističeskoeistočnikovedenie $i$ istoriâ russkogo âzyka 2004-2005, Moskva, s. 400-418. [Людоговский Ф.Б., 2006, Функционирование и эволючия служебного и четьего вариантов иерковнославянского Евангелия в эпоху книгопечатания: постановка проблемь, [в:] Лингвистическое источниковедение и история русского языка 2004-2005, Москва, c. $400-418$. 
Mihajlovskaâ N.G., 1978, Sinonimičeskaâ zamenâemost' slov v spiskah drevnerusskoj «Pčely:», [v:] Issledovaniâ po slovoobrazovaniû i leksikologii drevnerusskogo âzyka, Moskva, s. 139-172. [Михайловская Н.Г., 1978, Синонимическая заменяемость слов в списках древнерусской «Пчель»», [в:] Исследования по словообразованию и лексикологии древнерусского языка, Москва, с. 139-172.]

Panin L.G., 1995, Istoriâ cerkovnoslavânskogo âzyka i lingvističeskâa tekstologiâ, Novosibirsk. [Панин Л.Г., 1995, История церковнославянского языка и лингвистическая текстология, Новосибирск.]

Cejtlin R.M., 1977, Leksika staroslavânskogo âzyka, Moskva. [Цейтлин P.M., 1977, Лексика старославянского языка, Москва.]

\section{LEXICAL TRANSFORMATIONS OF CHURCH SLAVONIC TEXTS OF THE RUTHENIAN RECENSION}

\section{S U M M A R Y}

In this article two Church Slavonic old prints: the Ostrog Bible (1581) and the Jabłeczna Gospel Book (1771) - were subjected to collation with the lexis of the Ostromir Gospel Book. All the texts are the part of the Ruthenian recension. The purpose of the comparison was to show and explain the observed differences at the lexical level.

The confrontation allowed to differentiate between the language layers comprising the texts: the Greek, Moravian, West-Bulgarian, East-Bulgarian and Ruthenian ones. What is more, both old prints are identical (with the exception of three lexemes). Taking into consideration the few discrepancies, it can definitely be said that the Evangeliary of 1771 retained the pre-Niconian lexis virtually intact. Furthermore, juxtaposing proved that the Gospel aprakos differs from the Evangeliary and from the complete edition of the Bible not only in the organization of the content but also in the lexical and word formation means. 